ISAHP Article: Dixon-Ogbechi, Jagun, Ighomereho, Rahim, Haran/Determination of Promotional Strategy for Organizations in the Nigerian Insurance Industry using the AHP Model Submitted to the International Symposium of the Analytic Hierarchy Process 2014, Washington D.C., U.S.A.

\title{
DETERMINATION OF PROMOTIONAL STRATEGY FOR ORGANIZATIONS IN THE NIGERIAN INSURANCE INDUSTRY USING THE AHP MODEL
}

\author{
Bolajoko Nkemdinim Dixon-Ogbechi \\ Department of Business Administration \\ University of Lagos, Lagos, Nigeria \\ E-mail: dixonogbechi@yahoo.com \\ Sikuade Oladimeji Jagun \\ Sol Simon Investments \\ E-mail: sjagun@yahoo.com \\ Salome O. Ighomereho \\ Department of Economics and Business Studies \\ Redeemer's University, Ogun State, Nigeria \\ E-mail: ighomerehosalome@gmail.com \\ Ganiyu Ajao Rahim \\ Department of Business Administration \\ University of Lagos, Akoka - Yaba, Lagos, Nigeria \\ E-mail: Abdulrahimajao@yahoo.com \\ Elizabeth Marie Haran \\ Marketing and Decision Sciences Department \\ Salem State University, Salem, MA, USA \\ E-mail:eharan@salemstate.edu
}

\begin{abstract}
Several studies have revealed that insurance companies are experiencing low patronage and they have recommended the use of promotional strategy to create awareness and to boost customer patronage. However, research revealed that there are seven basic promotional tools that most companies in the service industry can use in their promotional mix. Thus, this paper applied the Analytic Hierarchy Process model (AHP) to assist managers in the Nigerian insurance companies evolve a promotional strategy by determining the best mix of the promotional elements to use, given certain criteria. To achieve this goal, the survey approach was used. The multistage sampling technique was used to select a sample of sixteen (16) insurance companies out of a population of 49 insurance companies in Lagos metropolis and questionnaires were administered to managers of these companies.
\end{abstract}

Keywords: Nigerian insurance companies, promotional strategy, promotional mix, Analytic Hierarchy Process model (AHP). 
ISAHP Article: Dixon-Ogbechi, Jagun, Ighomereho, Rahim, Haran/Determination of Promotional Strategy for Organizations in the Nigerian Insurance Industry using the AHP Model Submitted to the International Symposium of the Analytic Hierarchy Process 2014, Washington D.C., U.S.A.

\section{Introduction}

In order to effectively carryout marketing activities, organizations need to ensure they have the appropriate mix of the marketing elements. The basic elements of the marketing mix of an organization are popularly known with the acronym '4Ps' namely: Product, Promotion, Price and Place (McCarthy, 2002; Dixon-Ogbechi, Odugbemi and Aiyeku 2011). Thus, promotion is an important component of the marketing mix of a business organization. It is a critical aspect of organizations' overall marketing mix and a major determinant of their successes or failures (Shimp, 2007). Promotion is very essential for organizational survival because the target markets have to be informed about the product, its features, utility and availability; also, over the years, the need for promotional activities has increased because of stiff competition, widening of market, rapid changes in technology and tastes of customers (Bennet, 1995). In order to develop its promotional strategy, organizations have access to numerous forms of promotion elements, the combination of which is collectively referred to as the promotion mix or marketing communication mix (Kotler and Armstrong, 2010). Thus, the promotional mix is a set of elements/tools that a business can use to effectively communicate the benefits of its products or services to its customers (Kotler, 2001).

There are seven major promotional tools (advertising, personal selling, sales promotion, publicity, public relations, direct marketing, and sponsorship) that organizations can use (Kotler, 2000; Idris, Asokere, Ajemunigbohun, Oreshile and Olutade, 2012); these tools are used to develop the promotional strategy of an organization. The selection of promotional elements/tools to use depends on certain factors among which are the target audience/market, competitors' strategy, types and nature of product; message content, and organization budget (Kotler, 2001); the stage in the product life cycle, price and the funds available for promotional activities (Lancaster and Massingham (1999) cited by Idris et al., 2012); push and pull strategies, buyer readiness, type of distribution, promotion objectives, cost and availability of media (Reena, 2013); market size/concentration and customer information needs (Riley, 2012); actions of competitors (Nickels, McHugh and McHugh, 2002); and characteristics of the organization itself (Learn marketing, 2001). The challenge therefore is to develop a suitable promotional strategy by selecting the right mix of the promotional tools appropriate for a particular organization at a particular time given these criteria and then using it effectively to achieve organizational objectives (Kotler, 2000). Effective application of this can give an organization competitive advantage. Thus, organizations, including insurance companies, that understand the compelling need for effective marketing communication and take advantage of all the tools available to communicate effectively with its target market will have competitive advantage (Alireza, Ramak, and Abbas, 2011). This is of important in the insurance industry because research has revealed that financial service providers, a class to which insurance companies belong, are not perceived as highly trusted, so they might have difficulty in selling risk-based products using a single promotion tool (Cox (2007). The effort to promote insurance products and services is therefore quite distinct, just like it is in some other typical service based organizations.

Thus this study applied the Analytic Hierarchy Process model (AHP) to assist managers in the Nigerian insurance companies to evolve a promotional strategy by determining the best mix of the promotional elements to use given certain criteria.
International Symposium of
2
Washington, D. C.
the Analytic Hierarchy
June 29 - July 2, 2014
Process 
ISAHP Article: Dixon-Ogbechi, Jagun, Ighomereho, Rahim, Haran/Determination of Promotional Strategy for Organizations in the Nigerian Insurance Industry using the AHP Model Submitted to the International Symposium of the Analytic Hierarchy Process 2014, Washington D.C., U.S.A.

\section{Literature Review}

Organizations use various tools to promote their products. The major promotional tools used in physical product organizations are advertising, personal selling, sales promotion, publicity and public relations. The combination of these tools results in the promotional mix used for organizational promotional strategy. This is in support of Lovelock and Wirtz (2004)'s view that the promotion mix elements include: advertising, personal contact, publicity and public relations, sales promotion, instrumental material and corporate design. In addition to these, Kotler and Armstrong (2010) added direct marketing as being a promotional element. In other related studies, sponsorship was suggested as another element of the marketing communication mix (Fill, 2005; Kotler and Keller, 2009, Idris, Asokere, Ayodele, Ajemunigbohun, Oreshile and Olutade, 2012). With regards to service organizations, Okyere, Agypong, and Nyarku, (2011) confirmed that service firms use various tools of communication to promote their offerings in order to achieve their promotional objectives. Donelly and Peter (1998) identified advertising, sales promotion and personal selling as the three marketing communications tools used by service organizations, while Etzel, Walker, and Stanton, (2001) opined that the major promotion tools are advertising, personal selling, sales promotion and public relations. Therefore, for this study we assume that the seven major promotion tools used in service firms are Advertising, Personal Selling, Sales Promotions, Public Relation, Publicity, Direct Marketing and Sponsorship (Kotler, 2000; Idris et al., 2012). Advertising is viewed as any paid form of non-personal communication about an organization, good, service or an idea by an identified sponsor (Kotler and Armstrong, 2010). Personal selling, unlike other promotional tools, involves direct relationships between the seller and the prospect or customer (Kotler, 2001). Kotler and Armstrong (2010) claimed that personal selling is the most effective promotional mix elements in building up buyer's preferences, conviction and action in certain stage of purchase decision. Meidan (1996) is of the opinion that personal selling is probably the most important and frequently used element of the promotion tools in the financial services industry. Kurtz and Boone (2006) referred to sales promotion as any marketing activities used by manufacturers or producers to induce and provide extra value to consumers and dealers with the goal of stimulating consumer purchases and dealer effectiveness. Public relation is viewed by Kotler and Armstrong (2010) as a conscious and coordinated effort by organization to maintain good relations with the company's various stakeholders. Kotler and Armstrong (2010) further conceptualized publicity as the dissemination of information through personal or non-personal means, which is not directly paid for by the organization, and the organization is not the source. Direct marketing is the promotional element which entails using consumer direct channels to communicate with customers without the use of marketing middlemen (Kotler and Keller, 2006). And Lagae (2005) defined sponsorship as a form of business agreement between two parties, where the sponsor provides money, goods, services or know-how, whilst the sponsored party (individual, event or organization) offers rights and associations that the sponsor utilizes for commercial purposes.

The above notwithstanding, Achumba (2004) observed that in developing its promotional strategy, an organization might require some mixture of two or more of these elements given that the various promotional mix elements are not mutually exclusive. 
ISAHP Article: Dixon-Ogbechi, Jagun, Ighomereho, Rahim, Haran/Determination of Promotional Strategy for Organizations in the Nigerian Insurance Industry using the AHP Model Submitted to the International Symposium of the Analytic Hierarchy Process 2014, Washington D.C., U.S.A.

\section{Hypotheses/Objectives}

This study aims at determining:

a. the major promotional tools used by companies in the Nigerian insurance industry for their promotional strategy.

b. the relative importance of the criteria/factors taken into consideration by organizations in the Nigerian insurance industry when developing their promotional strategy.

c. the promotional strategy for companies in the Nigerian insurance industry using Analytic Hierarchy Process (AHP)..

\section{Research Design/Methodology}

This study used the AHP model to assist managers in the insurance industry to determine the relative importance of the promotional tools and use this knowledge to develop their promotional mix. At the highest level of the hierarchy is the goal which is being pursued, next at the middle or intermediate level of the hierarchy is the criterion, and at the lowest level are the alternatives to be evaluated (Saaty, 2001). In this study, the goal is to determine the promotional strategy for insurance companies and the criteria are the nine important factors influencing the choice of the promotional tools. At the lowest level are the promotion alternatives to be evaluated. These are the seven promotional tools/techniques. All the variables were identified from literature search. This is expressed as follows:

\section{The AHP Model of the Study}

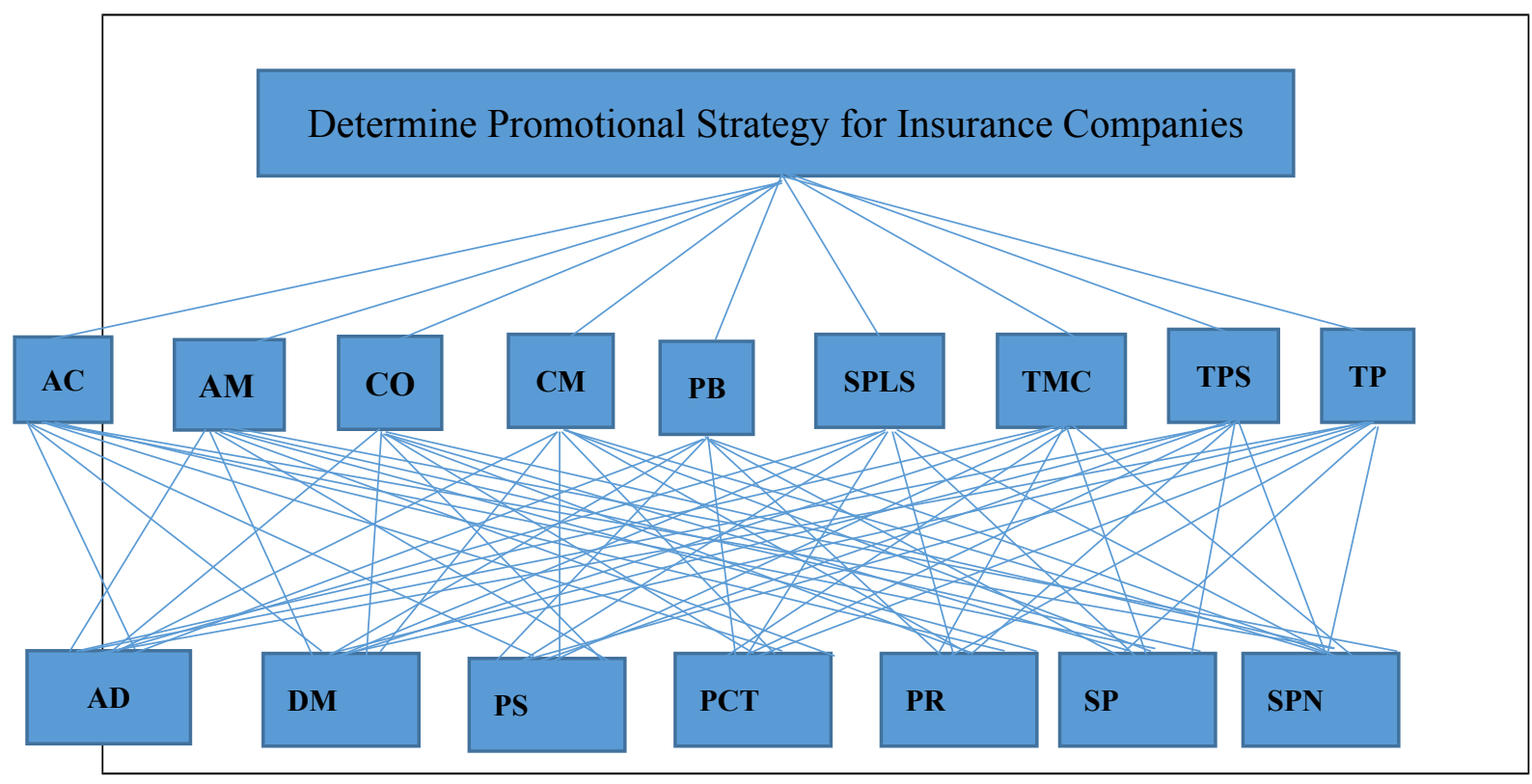

Where:

Goal $=$ Determine promotional strategy for insurance companies 
ISAHP Article: Dixon-Ogbechi, Jagun, Ighomereho, Rahim, Haran/Determination of Promotional Strategy for Organizations in the Nigerian Insurance Industry using the AHP Model Submitted to the International Symposium of the Analytic Hierarchy Process 2014, Washington D.C., U.S.A.

Criteria $=$ Actions of Competitors (AC), Availability of Media (AM), Communication Objective (CO), Cost of Media (CM), Promotional Budget (PB), Stage in Product Life Cycle (SPLC), Target Market Characteristics (TMC), Type of Distribution Strategy [Push or Pull] (TPS), and Type of Product (TP).

Alternatives $=$ Advertising (A), Direct Marketing (DM), Personal Selling (PS), Publicity (PCT), Public Relation (PR), Sales Promotions (SP) and Sponsorship (SPN).

\section{Data/Model Analysis}

Work on this aspect is still in progress.

\section{Limitations}

This will be written once this study has been concluded.

\section{Conclusions}

This will be written once the data has been analyzed.

\section{Key References}

Idris, Adekunle Abiodun, Asokere, Ayodele Stephen, Ajemunigbohun, Sunday Stephen, Oreshile, Ademola Sulaiman \& Olutade, Enitan Olumide (2012). "An empirical study of the efficacy of marketing communication mix elements in selected insurance companies in Nigeria". Australian Journal of Business and Management Research. 2 (05), 08-18.

Kotler, P \& Armstrong, G. (2010). Principles of Marketing, $13^{\text {th }}$ Edition, Pearson Educational, Incorporation.

Reena, J. (2013). 7 Important Factors That Affect "Promotion Mix", Retrieved October 20, 2013, from: http://www.shareyouressays.com/112830/7-importantfactors-that-affect-promotionmix

Saaty, T.L. (2000). Fundamentals of Decision making and Priority Theory with Analytical Hierarchy Process. Pittsburgh, PA: RWS Publications.

Saaty, A.S. \& Ansari, A.Z. (2011). Factors Critical in Marketing Strategies of Insurance Companies in Saudi Arabia, International Journal of Marketing Studies, 3(3), 104-121. http://dx.doi.org/10.5539/ijms.v3n3p104.

\section{Appendices}

Not needed for this proposal. 